Article

\title{
Escherichia coli Producing Extended-Spectrum $\beta$-lactamases (ESBL) from Domestic Camels in the Canary Islands: A One Health Approach
}

\author{
Isabel Carvalho ${ }^{1,2,3,4,5}$, María Teresa Tejedor-Junco ${ }^{6,7} \oplus$, Margarita González-Martín ${ }^{6,7}$,

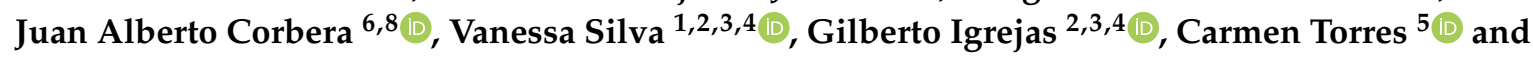 \\ Patrícia Poeta $1,4, *$ (1) \\ 1 Microbiology and Antibiotic Resistance Team (MicroART), Department of Veterinary Sciences, University of \\ Trás-os-Montes and Alto Douro, 5000-801 Vila Real, Portugal; isabelbarrosocarvalho@utad.pt (I.C.); \\ vanessasilva@utad.pt (V.S.) \\ 2 Department of Genetics and Biotechnology, UTAD, 5000-801 Vila Real, Portugal; gigrejas@utad.pt \\ 3 Functional Genomics and Proteomics Unit, UTAD, 5000-801 Vila Real, Portugal \\ 4 Laboratory Associated for Green Chemistry (LAQV-REQUIMTE), New University of Lisbon, \\ 2829-516 Monte da Caparica, Portugal \\ 5 Area Biochemistry and Molecular Biology, University of La Rioja, 26006 Logroño, Spain; \\ carmen.torres@unirioja.es \\ 6 Research Institute of Biomedical and Health Sciences, University of Las Palmas de Gran Canaria, \\ 35001 Canary Islands, Spain; mariateresa.tejedor@ulpgc.es (M.T.T.-J.); \\ margaritarosa.gonzalez@ulpgc.es (M.G.-M.); juan.corbera@ulpgc.es (J.A.C.) \\ 7 Department of Clinical Sciences, University of Las Palmas de Gran Canaria, 35001 Canary Islands, Spain \\ 8 Department of Animal Pathology, Veterinary School, University of Las Palmas de Gran Canaria, \\ 35001 Canary Islands, Spain \\ * Correspondence: ppoeta@utad.pt; Tel./Fax: +351-259-350-466
}

Received: 22 June 2020; Accepted: 27 July 2020; Published: 29 July 2020

Simple Summary: Extended-spectrum beta-lactamase (ESBL) producing Escherichia coli is an important problem in hospital settings. Camels are known to harbor multidrug-resistant Gram-negative bacteria and to be involved in the transmission of various microorganisms to humans. Fecal samples of 58 camels were recovered in the Canary Islands for detection and characterization of cefotaxime-resistant $\left(C T X^{\mathrm{R}}\right)$ and ESBL-producing E. coli isolates. Five samples carried CTX ${ }^{\mathrm{R}}$ E. coli isolates and two of them contained ESBL-positive E. coli (3.4\%) with the following characteristics: (ESBL/phylogroup/sequence type): CTX-M-15/A/ST3018 and CTX-M-15/B1/ST69. The three remaining isolates recovered from $C T X$-supplemented plates were ascribed to phylogroup- $\mathrm{B}_{1}$. Due to the participation of these animals in touristic activities in the region, the potential transference of ESBL-positive bacteria between humans and animals could happen and should be further monitored.

Abstract: Objective: This work aimed to determine the carriage rate of ESBL-producing Escherichia coli as well as their genetic characteristics in camels from the Canary Islands, Spain. Methods: Fecal samples were recovered from 58 healthy camels from Gran Canaria $(n=32)$ and Fuerteventura Islands $(n=26)$ during July 2019. They were seeded on MacConkey (MC) agar no supplemented and supplemented (MC + CTX) with cefotaxime $(2 \mu \mathrm{g} / \mathrm{mL})$. Antimicrobial susceptibility was determined by disk diffusion test (CLSI, 2018). The presence of $b l a_{\mathrm{CTX}-\mathrm{M}}, b l a_{\mathrm{SHV}}, b l a_{\mathrm{TEM}}, b l a_{\mathrm{CMY}-2}$ and $b l a_{\mathrm{OXA}-1 / 48}$ genes was tested by PCR/sequencing. Furthermore, the $m c r-1$ (colistin resistance), tet $\mathrm{A} /$ tet $\mathrm{B}$ (tetracycline resistance), int 1 (integrase of class 1 integrons) and $s t x_{1,2}$ genes were analyzed. Phylogenetic groups and sequence types were determined by specific-PCR/sequencing for selected isolates. Results: E. coli was obtained from all the 58 camels in MC media $(100 \%)$ and in five of them in MC + CTX media (8.6\%). Furthermore, $63.8 \%$ of $E$. coli isolates recovered from MC agar were susceptible to all the antibiotics tested. The five E. coli isolates recovered from MC + CTX media were characterized and 
two of them were ESBL-producers (3.4\%). Both ESBL-producer isolates carried the $b l a_{\mathrm{CTX}-\mathrm{M}-15}$ gene and belonged to the lineages ST3018 (phylogroup A) and ST69 (phylogroup B1). The 3 ESBL-negative isolates recovered from MC-CTX plates were ascribed to phylogroup- $\mathrm{B}_{1}$. Conclusions: Camels can be a source of ESBL-producer bacteria, containing the widespread bla lineages ST3018 and ST69.

Keywords: antimicrobial resistance; extended-spectrum $\beta$-lactamases; Escherichia coli; camels

\section{Introduction}

During the last decade, different studies have been published in Europe regarding antimicrobial resistance among Enterobacteriaceae in wild animals [1-4], pets [5-9] and humans [10-13]. The excessive and sometimes inappropriate antibiotic use in both human and veterinary medicine has been considered as one of the main contributors of the selection and dissemination of multidrug-resistant (MDR) bacteria [14,15]. According to the World Health Organization (WHO) [16], the abuse and misuse of these drugs can also lead to this global health concern and compromise prevention and treatment of an increasing range of infections caused by bacteria.

Escherichia coli, belonging to the Enterobacteriaceae family, is a normal inhabitant of the human intestine, but at the same time, it is an important opportunistic pathogen associated with severe sepsis and urinary infections, among other infections at hospital level $[17,18]$. In the case of camels, diarrhea and other infectious diseases are considered to be the main causes of economic loss associated with poor growth, medication costs, and animal death [19]. In the last few years, the number of researches on the epidemiology of MDR bacteria has increased in both hospital and community settings around the world, with special attention to extended-spectrum $\beta$-lactamase (ESBL), plasmid mediated AmpC $\beta$-lactamase (pAmpC), and carbapenemase production in Enterobacteriaceae [20]. The genes encoding these enzymes are frequently plasmid-located and can be horizontally transferred to other bacteria [21]. The spread of E. coli isolates producing CTX-M-type beta-lactamases is mostly responsible for the increased incidence of ESBL, especially CTX-M-15 variant, both in animals and humans [18,22-25].

Regarding the collaborative and multi-disciplinary "One Health" approach, the interaction between animal, human, and environmental health is required. In this line, Canarian camels are in contact with humans, and both with the environment, disseminating the presence of potential resistant bacteria between the three axes of One Health.

To our knowledge, this is the first report on ESBL-producing bacteria performed in camels from Europe, specifically, the Canary Islands. Even though antibiotic resistance in camels has been less studied than in other domestic animals worldwide [26-30], they might have an important role in the spread of ESBL/pAmpC bacteria [19,24,31,32]. Due to the participation of camels in touristic activities in the region, the close interaction between camels and humans facilitates the potential transference of ESBL-positive bacteria, highlighting the need for further work in this area. The aim of this research was to determine the carriage rate of ESBL-producing E. coli as well as their genetic lineages in camels from Fuerteventura and Gran Canaria (Canary Islands), Spain.

\section{Materials and Methods}

\subsection{Animals and Sampling}

A total of 58 fecal samples were recovered from apparently healthy camels (Camelus dromedaries) used in touristic activities from Gran Canaria $(n=32)$ and Fuerteventura $(n=26)$ Islands during July 2019 (Figure S1). It is important to note that these animals were in contact with humans in touristic activities (domestic animals) and the camels from the same island were in contact with each other. One fecal sample per animal was obtained rectally using a sterile cotton swab during a veterinarian 
intervention and all samples were dispatched immediately to the Research Institute of Biomedical and Health Sciences (University of Las Palmas de Gran Canaria, Spain).

\subsection{Escherichia coli Isolation}

The fecal samples were inoculated onto MacConkey agar plates non supplemented (MC) and supplemented with $2 \mu \mathrm{g} / \mathrm{L}$ of cefotaxime (MC $+\mathrm{CTX})$ for cefotaxime resistant $\left(\mathrm{CTX} \mathrm{R}^{\mathrm{R}}\right) \mathrm{E}$. coli recovery. The plates were incubated for $24 \mathrm{~h}$ at $37^{\circ} \mathrm{C}$ and colonies growing with a typical morphology for $E$. coli (red or pink, non-mucoid colonies) were recovered; they were identified by classical biochemical methods named IMViC (Indol, Methyl-red, Voges-Proskauer and Citrate) and also for Analytical Profile Index (API 20E gallery). In order to confirm the bacterial species identification, the matrix-assisted laser desorption/ionization time-of-flight mass spectrometry method (MALDI-TOF MS, Bruker) was applied in the Laboratory of Biochemistry and Molecular Biology in the University of La Rioja (Logroño, Spain). One E. coli per sample on each of the media used was kept and characterized by genetic methods.

\subsection{Susceptibility Testing}

Antimicrobial susceptibility testing was performed on Mueller-Hinton agar using the disk diffusion method, according with Clinical Laboratory Standards Institute standard guidelines CLSI, $2018^{33}$. E. coli isolates were tested against the following antimicrobial agents ( $\mu \mathrm{g} / \mathrm{disk})$ : ampicillin (10), amoxicillin + clavulanic acid $(20+10)$, cefoxitin (30), cefotaxime (30), ceftazidime (30), aztreonam (30), imipenem (10), tetracycline (30), ciprofloxacin (5), trimethoprim-sulfamethoxazole $(1.25+23.75)$, gentamicin (10), tobramycin (10), streptomycin (10), and amikacin (30). The strains were recorded as susceptible, intermediate, or resistant according to the zone diameter interpretative standards recommended by CLSI (2018) [33]. The detection of ESBL production was carried out using three disks of antibiotics in the same line: cefotaxime, ceftazidime, and amoxicillin/clavulanic acid (CLSI, 2018) ${ }^{33}$. Based on the disc diffusion method for these three antimicrobials, we concluded if the isolate were ESBL positive when was visible the ghost zone between these antibiotics.

\subsection{DNA Extraction and Quantification}

Genomic DNA from MDR strains was extracted using the InstaGene Matrix (BioRad, Hercules, CA, USA), according to the manufacturer's instructions. In order to quantify the DNA concentration and the level of purity, the absorbance readings were taken at 260 and $280 \mathrm{~nm}$ (Spectrophotometer ND-100, Nanodrop Thermo Fisher Scientific, Wilmington, DE, USA).

\subsection{Antibiotic Resistance Genes}

The genetic basis of resistance was investigated using PCR/sequencing of the obtained amplicons. Positive controls of the University of La Rioja (Logroño, Spain) were used in this study.

The presence of the $b l a_{\mathrm{CTX}-\mathrm{M}}$ (groups 1 and 9), bla $a_{\mathrm{SHV}}, b l a_{\mathrm{TEM}}, b l a_{\mathrm{OXA}-1,} b l a_{\mathrm{OXA} 48}, b l a_{\mathrm{CMY}-2}$, and bla $a_{\mathrm{KPC}}$ genes [34] was tested by PCR/sequencing [35,36]. It is important to note that CTX-M genes were tested for ESBL-positive isolates while the isolates with the typical AmpC phenotype, the presence of $b l a_{\mathrm{CMY}-2}$ gene was tested. Furthermore, the $m c r-1$ (colistin resistance), tet $\mathrm{A} /$ tet $\mathrm{B}$ (tetracycline resistance), int 1 genes (integrase of class 1 integrons), as well as the $s t x_{1,2}$ genes were also analyzed. Phylogenetic classification of E. coli isolates was performed according to the existence of chuA, yjaA, and TSPE4.C2 [37].

\subsection{Multilocus Sequence Typing of E. coli Isolates}

The multilocus sequence typing (MLST) with seven housekeeping genes (icd, fum $\mathrm{C}, m d h$, adk, recA, purA, and gyrB) was carried out in the two ESBL-producing isolates, according to the protocol for E. coli on the PubMLST site [38]. The allele combination was determined after sequencing the seven genes, and the sequence type (ST) and clonal complex (CC) was identified. 


\section{Results and Discussion}

\subsection{Characteristics of E. coli Isolates Obtained in Non-Supplemented Media (MC)}

E. coli isolates were recovered from all fecal samples in MC plates, and a collection of 58 isolates were obtained (one/sample). The percentages of antimicrobial resistance in these E. coli isolates are presented in Table 1. Most of our isolates were susceptible to all antibiotics tested $(n=37$, $63.8 \%$ ) and only two isolates (5.2\%) showed a MDR phenotype (resistance to at least three families of antibiotics). Resistance to ampicillin was detected in $34.5 \%$ of isolates and to streptomycin in $10.3 \%$. None of the isolates obtained in MC plates (without antibiotic supplementation) showed resistance to amoxicillin-clavulanic acid, broad spectrum cephalosporins (cefotaxime and ceftazidime) aminoglycosides (except streptomycin), or imipenem. Moreover, all these isolates showed susceptibility to ciprofloxacin (Table 1 ).

Table 1. Resistance phenotype of E. coli isolates recovered of fecal samples of healthy camels from MC plates (non-supplemented with cefotaxime).

\begin{tabular}{ccc}
\hline${\text { Resistance Phenotype }{ }^{\mathbf{a}}}$ & Number of Isolates & Origin (Number of Samples) $^{\mathbf{b}}$ \\
\hline Susceptible & 37 & GC (15), FV (22) \\
AMP & 15 & FV (3), GC (12) \\
AMP, S & 3 & GC (3) \\
S & 1 & GC \\
AMP, S, TET, SXT & 1 & GC \\
AMP, S, TET & 1 & FV \\
\hline
\end{tabular}

Legend: ${ }^{a}$ AMP-ampicillin; S—streptomycin; TET—-tetracycline; SXT—trimethoprim-sulfamethoxazole; ${ }^{b}$ GC Gran Canaria; FV-Fuerteventura.

To our knowledge, there were few reports in which fecal E. coli isolates, recovered without antibiotic selection from healthy camels, were studied for antimicrobial resistance. In this line, E. coli isolates were detected in fecal samples from apparently healthy camels in Bangladesh [39] and, in contrast, from diarrheic camel calves in Saudi Arabia [40]; however, they lacked data about antibiotic resistance genes.

\subsection{Characteristics of E. coli Obtained in Supplemented Media (MC-CTX)}

Escherichia coli isolates were recovered in five of the 58 tested samples, when they were cultured in MC + CTX plates. Table 2 shows the characteristics of these isolates.

Table 2. Antimicrobial resistance phenotype and genotype of Escherichia coli isolates recovered of fecal samples of healthy camels from MC + CTX plates (supplemented with cefotaxime).

\begin{tabular}{|c|c|c|c|c|c|c|c|}
\hline Isolate Number & Origin $^{a}$ & ESBL $^{b}$ & Resistance Phenotype $^{c}$ & $\beta$-Lactamases & Resistance Genes & PG $^{d}$ & MLST $^{\mathrm{e}}$ \\
\hline X1848 & GC & $\mathrm{P}$ & AMP, CTX, CAZ, TET, S, SXT & CTX-M-15, TEM-1 & tet $\mathrm{A}$, tet $\mathrm{B}$, int 1 & A & ST3018 \\
\hline $\mathrm{X} 2263$ & FV & $\mathrm{P}$ & AMP, AMC, CTX, CAZ, SXT & CTX-M-15 & - & B1 & ST69 \\
\hline X1929 & GC & $\mathrm{N}$ & AMP, FOX, CTX, CAZ & - & - & B1 & \\
\hline X1850 & FV & $\mathrm{N}$ & AMP, AMC, CTX, CAZ & - & - & B1 & \\
\hline
\end{tabular}

Legend: ${ }^{a}$ GC—Gran Canaria; FV—Fuerteventura; ${ }^{b} \mathrm{P}-$ Positive, N-Negative; ${ }^{\mathrm{c}}$ AMP—ampicillin; CTX—cefotaxime; CAZ—ceftazidime; TET—-tetracycline; S—streptomycin; STX—trimethoprim-sulfamethoxazole; AMC—amoxicillinclavulanic acid; FOX—cefoxitin. ${ }^{\mathrm{d}}$ PG—Phylogroup; ${ }^{\mathrm{e}}$ MLST-MultiLocus Sequence Typing.

All of these five isolates were resistant to ampicillin, cefotaxime, and ceftazidime and three of them also to amoxicillin + clavulanic acid. Resistance to tetracycline and trimethoprim + sulfamethoxazole was found in one and two isolates, respectively (Table 2). We also detected one strain with intermediate resistance to imipenem (isolate X2263), although it lacked the bla $a_{\mathrm{OXA} 48}$ and $b l a_{\mathrm{KPC}}$ genes.

Two of the $\mathrm{CTX}^{\mathrm{R}}$ E. coli isolates were ESBL-producers, representing $3.4 \%$ of the total animals tested. A higher prevalence of ESBL-positive E. coli $(26.9 \%)$ was found in a previous study in camels 
from Saudi Arabia [41]. One of the ESBL-producing E. coli isolates of our study was obtained from a camel of Gran Canaria and it showed the following resistant genotype: $b l a_{\mathrm{CTX}} \mathrm{M}-15, b l a_{\mathrm{TEM}-1}$, tet $\mathrm{A}$, and tet $\mathrm{B}$; this isolate also carried the int gene encoding the integrase of class 1 integrons. Moreover, the other ESBL-positive isolate was collected from a camel of Fuerteventura and it was positive for bla $_{\text {CTX-M-15 }}$ gene (Table 2). The detection of ESBL-producing isolates in camels in this study could represent a public health concern if transmitted to humans [19]. These results are similar to the data obtained in the same animal species in a previous study, in which three ESBL-E. coli isolates carried bla $a_{\mathrm{CTX}-\mathrm{M}-15}(n=2)$ and bla $a_{\mathrm{CTX}-\mathrm{M}-1}$ genes $(n=1)$ [24]. Furthermore, Ben Sallem, et al. [42] detected the presence of bla CTX-M-1 $_{1}$ in one isolate from a dromedary in Tunisia.

The three CTX ${ }^{R}$ and ESBL-negative isolates recovered in MC + CTX plates of our study belonged to the $\mathrm{B}_{1}$ phylogroup, and they did not carry any of the beta-lactamase genes tested, including $b l a_{\mathrm{CMY}-2}$ (Table 2); these strains might carry other non-tested acquired AmpC beta-lactamases, or could present hyperproduction of the chromosomal AmpC beta-lactamase [43].

The $m c r-1$ determinant, encoding colistin resistance, was studied in all E. coli isolates of this work, and all of them were $m c r-1$ negative. However, other studies done in camels from different African cities found E. coli harboring the $m c r-1$ gene [24,32]. None of our isolates were positive for the $s t x 1$ or $s t x 2$ genes, contrasting with the results obtained in a recent study done on fecal samples of African dromedary camels [44].

The two CTX-M-15-positive isolates were ascribed to the sequence type ST3018 (phylogroup A) and ST69 (phylogroup B1; Table 2). These results agree with the ones of Saidani, et al. [24] and Bessalah, et al. [19], suggesting the predominance of commensal E. coli isolates (phylogroups A and $B_{1}$ ) in healthy camels from Tunisia. Furthermore, these results are in line with the detection of $B_{1}$ phylogroup in the E. coli isolated from fecal sample from a dromedary in Tunisia [42].

This unusual ST lineage (ST3018) had not been reported before in either humans or in camels' isolates. There are only two recent reports on ST3018 E. coli, one on isolates from dairy cattle in the USA [45] and another one on isolates from a poultry farm in Ghana [46], associated with the $b l a_{\mathrm{CTX}-\mathrm{M}-15}$ gene. Additionally, our data revealed the presence of ST3018-CTX-M-15 E. coli, which should be considered a recent lineage detected in different ecosystems with relevance for animals and with potential transmission to humans (Table 2).

Regarding the lineage ST69, detected in a CTX-M-15-positive E. coli isolate in this study, it has been previously referred to as a pandemic clonal lineage in humans implicated in extraintestinal infections [45]. The ST69 clone was previously reported as well among dairy cattle-associated E. coli carrying $b l a_{\mathrm{CTX}-\mathrm{M}-65}$ gene in the Washington State [45]. Our results are also in line with the detection

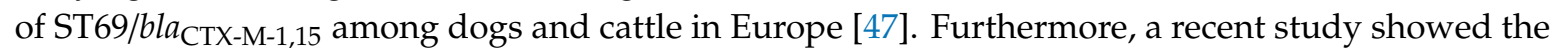
presence of ST69/ bla $a_{\mathrm{CTX}-\mathrm{M}-14,15}$ among febrile urinary tract infections in children from France [48]. Interestingly, the dogs and humans of the family carried an identical CTX-M-group-9 E. coli ST69 strain, indicating interspecies transmission [49]. The same lineage was also present in both avian (gulls) and human populations in Chile [50].

Very few reports have been produced on camels concerning the prevalence and characterization of ESBL-producer E. coli in the fecal microbiota of healthy camels, and most of the studies have focused on E. coli isolates in other domestic animals [51-53] or in camels only from the Africa continent $[19,24,41]$.

To our knowledge, this is the first study related to commensal ESBL-producing E. coli isolates recovered from camels in Spain (Canary Islands) and also the first report in Europe. This research is also an important contribution as a One Health approach.

\section{Conclusions}

This study demonstrated that camels could become a source of ESBL-producing E. coli isolates associated with recent clones ST3018 and ST69. For the first time in Spain and Europe, our study reported the presence and possible dissemination of the bla $a_{\mathrm{CTX}-\mathrm{M}-15}$ gene in $E$. coli isolates of fecal samples of camels in the Canary Islands, which could potentially be transferred to close-contact humans. 
These resistant bacteria should be monitored in the future, mostly in this type of animals that lives in such close contact with humans. Further research with a larger number of camels will be necessary to elucidate the role of $E$. coli in healthy and sick camels.

Supplementary Materials: The following are available online at http:/www.mdpi.com/2076-2615/10/8/1295/s1, Figure S1-Origin of camels' samples: Fuerteventura and Gran Canaria (Canary Islands, Spain).

Author Contributions: Conceptualization, M.T.T.-J. and P.P.; methodology, I.C., C.T. and P.P.; validation, V.S., G.I., C.T. and P.P.; investigation, I.C.; resources, M.T.T.-J., M.G.-M. and J.A.C.; funding acquisition: C.T. and P.P.; writing - original draft preparation, I.C.; supervision, G.I., C.T. and P.P. All authors have read and agreed to the published version of the manuscript.

Funding: Isabel Carvalho and Vanessa Silva gratefully acknowledge the PhD financial support of "Fundação para a Ciência e Tecnologia" (FCT - Portugal), through the references SFRH/BD/133266/2017 and SFRH/BD/137947/2018 (Medicina Clínica e Ciências da Saúde). Experimental work performed in the University of La Rioja was financed by the project SAF 2016-76571-R of the Agencia Estatal de Investigación (AEI) of Spain and the Fondo Europeo de Desarrollo Regional (FEDER) of EU.

Conflicts of Interest: The authors confirm that there are no known conflicts of interest associated with this publication. Preliminary results were presented as an abstract and poster presentation at the XVI Congresso Internacional Veterinário Montenegro, February 2020, Portugal.

\section{References}

1. Marinho, C.; Igrejas, G.; Gonçalves, A.; Silva, N.; Santos, T.; Monteiro, R.; Gonçalves, D.; Rodrigues, T.; Poeta, P. Azorean wild rabbits as reservoirs of antimicrobial resistant Escherichia coli. Anaerobe 2014, 30, 116-119. [CrossRef] [PubMed]

2. Costa, D.; Poeta, P.; Saenz, Y.; Vinue, L.; Coelho, A.C.; Matos, M.; Rojo-Bezares, B.; Rodrigues, J.; Torres, C. Mechanisms of antibiotic resistance in Escherichia coli isolates recovered from wild animals. Microb. Drug Resist. 2008, 14, 71-77. [CrossRef] [PubMed]

3. Radhouani, H.; Poeta, P.; Goncalves, A.; Pacheco, R.; Sargo, R.; Igrejas, G. Wild birds as biological indicators of environmental pollution: Antimicrobial resistance patterns of Escherichia coli and enterococci isolated from common buzzards (Buteo buteo). J. Med. Microbiol. 2012, 61, 837-843. [CrossRef] [PubMed]

4. Wang, J.; Ma, Z.-B.; Zeng, Z.-L.; Yang, X.-W.; Huang, Y.; Liu, J.-H. The role of wildlife (wild birds) in the global transmission of antimicrobial resistance genes. Zool Res. 2017, 38, 55-80. [CrossRef]

5. Belas, A.; Salazar, A.S.; Gama, L.T.; Couto, N.; Pomba, C. Risk factors for faecal colonisation with Escherichia coli producing extended-spectrum and plasmid-mediated AmpC $\beta$-lactamases in dogs. Vet. Rec. 2014, 175, 202. [CrossRef]

6. Marques, C.; Gama, L.T.; Belas, A.; Bergstrom, K.; Beurlet, S.; Briend-Marchal, A.; Broens, E.M.; Costa, M.; Criel, D.; Damborg, P.; et al. European multicenter study on antimicrobial resistance in bacteria isolated from companion animal urinary tract infections. BMC Vet. Res. 2016, 12, 213. [CrossRef]

7. Bourne, J.A.; Chong, W.L.; Gordon, D.M. Genetic structure, antimicrobial resistance and frequency of human associated Escherichia coli sequence types among faecal isolates from healthy dogs and cats living in Canberra, Australia. PLoS ONE 2019, 14, e0212867. [CrossRef]

8. Zogg, A.L.; Simmen, S.; Zurfluh, K.; Stephan, R.; Schmitt, S.N.; Nuesch-Inderbinen, M. High Prevalence of Extended-Spectrum beta-Lactamase Producing Enterobacteriaceae Among Clinical Isolates From Cats and Dogs Admitted to a Veterinary Hospital in Switzerland. Front. Vet. Sci. 2018, 5, 62. [CrossRef]

9. Carvalho, I.; Alonso, C.; Silva, V.; Pimenta, P.; Cunha, R.; Martins, C.; Igrejas, G.; Torres, C.; Poeta, P. Extended-Spectrum Beta-Lactamase-Producing Klebsiella pneumoniae Isolated from Healthy and Sick Dogs in Portugal. Microb. Drug Resist. 2020, 26, 709-715. [CrossRef]

10. Cerquetti, M.; Giufrè, M.; García-Fernández, A.; Accogli, M.; Fortini, D.; Luzzi, I.; Carattoli, A. Ciprofloxacin-resistant, CTX-M-15-producing Escherichia coli ST131 clone in extraintestinal infections in Italy. Clin. Microbiol. Infect. 2010, 16, 1555-1558. [CrossRef]

11. Valentin, L.; Sharp, H.; Hille, K.; Seibt, U.; Fischer, J.; Pfeifer, Y.; Michael, G.B.; Nickel, S.; Schmiedel, J.; Falgenhauer, L.; et al. Subgrouping of ESBL-producing Escherichia coli from animal and human sources: An approach to quantify the distribution of ESBL types between different reservoirs. Int. J. Med. Microbiol. 2014, 304, 805-816. [CrossRef] [PubMed] 
12. Ulstad, C.R.; Solheim, M.; Berg, S.; Lindbaek, M.; Dahle, U.R.; Wester, A.L. Carriage of ESBL/AmpC-producing or ciprofloxacin non-susceptible Escherichia coli and Klebsiella spp. in healthy people in Norway. Antimicrob. Resist. Infect. Control 2016, 5, 57. [CrossRef] [PubMed]

13. Schmiedel, J.; Falgenhauer, L.; Domann, E.; Bauerfeind, R.; Prenger-Berninghoff, E.; Imirzalioglu, C.; Chakraborty, T. Multiresistant extended-spectrum $\beta$-lactamase-producing Enterobacteriaceae from humans, companion animals and horses in central Hesse, Germany. BMC Microbiol. 2014, 14, 187. [CrossRef] [PubMed]

14. Bengtsson-Palme, J.; Angelin, M.; Huss, M.; Kjellqvist, S.; Kristiansson, E.; Palmgren, H.; Larsson, D.G.J.; Johansson, A. The Human Gut Microbiome as a Transporter of Antibiotic Resistance Genes between Continents. Antimicrob. Agents Chemother. 2015, 59, 6551-6560. [CrossRef] [PubMed]

15. Carvalho, I.; Silva, N.; Carrola, J.; Silva, V.; Currie, C.; Igrejas, G.; Poeta, P. Antibiotic Resistance. In Antibiotic Drug Resistance; Capelo-Martinez, J.-L., Lgrejas, G., Eds.; John Wiley \& Sons: Hoboken, NJ, USA, 2019; pp. 239-259.

16. WHO World Health Organization. Global Priority List of Antibiotic-Resistant Bacteria to Guide Research. Discovery, and Development of New Antibiotics. 2017. Available online: http://www.who.int/medicines/ publications/WHO-PPL-Short_Summary_25Feb-ET_NM_WHO.pdf (accessed on 10 January 2020).

17. Iredell, J.; Brown, J.; Tagg, K. Antibiotic resistance in Enterobacteriaceae: Mechanisms and clinical implications. BMJ 2016, 352, h6420. [CrossRef] [PubMed]

18. Day, M.J.; Rodriguez, I.; van Essen-Zandbergen, A.; Dierikx, C.; Kadlec, K.; Schink, A.K.; Wu, G.; Chattaway, M.A.; DoNascimento, V.; Wain, J.; et al. Diversity of STs, plasmids and ESBL genes among Escherichia coli from humans, animals and food in Germany, the Netherlands and the UK. J. Antimicrob. Chemother. 2016, 71, 1178-1182. [CrossRef]

19. Bessalah, S.; Fairbrother, J.M.; Salhi, I.; Vanier, G.; Khorchani, T.; Seddik, M.M.; Hammadi, M. Antimicrobial resistance and molecular characterization of virulence genes, phylogenetic groups of Escherichia coli isolated from diarrheic and healthy camel-calves in Tunisia. Comp. Immunol. Microbiol. Infect. Dis. 2016, 49, 1-7. [CrossRef]

20. Dziri, R.; Klibi, N.; Alonso, C.A.; Jouini, A.; Ben Said, L.; Chairat, S.; Bellaaj, R.; Boudabous, A.; Ben Slama, K.; Torres, C. Detection of CTX-M-15-Producing Escherichia coli Isolates of Lineages ST131-B2 and ST167-A in Environmental Samples of a Tunisian Hospital. Microb. Drug Resist. 2016, 22, 399-403. [CrossRef]

21. Alcala, L.; Alonso, C.A.; Simon, C.; Gonzalez-Esteban, C.; Oros, J.; Rezusta, A.; Ortega, C.; Torres, C. Wild Birds, Frequent Carriers of Extended-Spectrum $\beta$-Lactamase (ESBL) Producing Escherichia coli of CTX-M and SHV-12 Types. Microb. Ecol. 2016, 72, 861-869. [CrossRef]

22. Alonso, C.A.; Zarazaga, M.; Ben Sallem, R.; Jouini, A.; Ben Slama, K.; Torres, C. Antibiotic resistance in Escherichia coli in husbandry animals: The African perspective. Lett. Appl. Microbiol. 2017, 64, 318-334. [CrossRef] [PubMed]

23. O'Keefe, A.; Hutton, T.A.; Schifferli, D.M.; Rankin, S.C. First Detection of CTX-M and SHV Extended-Spectrum $\beta$-Lactamases in Escherichia coli Urinary Tract Isolates from Dogs and Cats in the United States. Antimicrob. Agents Chemother. 2010, 54, 3489-3492. [CrossRef]

24. Saidani, M.; Messadi, L.; Mefteh, J.; Chaouechi, A.; Soudani, A.; Selmi, R.; Daaloul-Jedidi, M.; Ben Chehida, F.; Mamlouk, A.; Jemli, M.H.; et al. Various Inc-type plasmids and lineages of Escherichia coli and Klebsiella pneumoniae spreading blaCTX-M-15, blaCTX-M-1 and mcr-1 genes in camels in Tunisia. J. Glob. Antimicrob. Resist. 2019, 19, 280-283. [CrossRef]

25. Zorgani, A.; Almagatef, A.; Sufya, N.; Bashein, A.; Tubbal, A. Detection of CTX-M-15 Among Uropathogenic Escherichia coli Isolated from Five Major Hospitals in Tripoli, Libya. Oman. Med. J. 2017, 32, 322-327. [CrossRef] [PubMed]

26. Carvalho, I.; Del Campo, R.; Sousa, M.; Silva, N.; Carrola, J.; Marinho, C.; Santos, T.; Carvalho, S.; Novoa, M.; Quaresma, M.; et al. Antimicrobial resistant Escherichia coli and Enterococcus spp. isolated from Miranda Donkey (Equus asinus): An old problem from a new source with a different approach. J. Med. Microbiol. 2017, 66, 191-202. [CrossRef] [PubMed]

27. Rumi, M.; Mas, J.; Elena, A.; Cerdeira, L.; Muñoz, M.E.; Lincopan, N.; Gentilini, É.R.; Conza, J.; Gutkind, G. Co-Occurrence of Clinically Relevant $\beta$-Lactamases and Mcr-1 Encoding Genes in Escherichia Coli from Companion Animals in Argentina. Vet. Microbiol. 2019, 230, 228-234. [CrossRef] 
28. Saputra, S.; Jordan, D.; Mitchell, T.; Wong, H.S.; Abraham, R.J.; Kidsley, A.; Turnidge, J.; Trott, D.J.; Abraham, S. Antimicrobial resistance in clinical Escherichia coli isolated from companion animals in Australia. Vet. Microbiol. 2017, 211, 43-50. [CrossRef] [PubMed]

29. Suay-Garcia, B.; Galan, F.; Rodriguez-Iglesias, M.A.; Perez-Gracia, M.T. Detection and Characterization of Extended-Spectrum Beta-Lactamases-Producing Escherichia coli in Animals. Vector Borne Zoonotic Dis. 2019, 19, 115-120. [CrossRef]

30. Ahmed, M.O.; Clegg, P.D.; Williams, N.J.; Baptiste, K.E.; Bennett, M. Antimicrobial resistance in equine faecal Escherichia coli isolates from North West England. Ann. Clin. Microbiol. Antimicrob. 2010, 9, 12. [CrossRef]

31. Adamu, M.S.; Ugochukwu, I.C.I.; Idoko, S.I.; Kwabugge, Y.A.; Abubakar, N.S.; Ameh, J.A. Virulent gene profile and antibiotic susceptibility pattern of Shiga toxin-producing Escherichia coli (STEC) from cattle and camels in Maiduguri, North-Eastern Nigeria. Trop. Anim. Health Prod. 2018, 50, 1327-1341. [CrossRef] [PubMed]

32. Rhouma, M.; Bessalah, S.; Salhi, I.; Theriault, W.; Fairbrother, J.M.; Fravalo, P. Screening for fecal presence of colistin-resistant Escherichia coli and mcr-1 and mcr-2 genes in camel-calves in southern Tunisia. Acta Vet. Scand. 2018, 60, 35. [CrossRef]

33. CLSI Clinical and Laboratory Standards Institute. Performed Standards for Antimicrobial Susceptibility Testing, 28th ed.; CLSI: Wayne, PA, USA, 2018.

34. Ben Tanfous, F.; Alonso, C.A.; Achour, W.; Ruiz-Ripa, L.; Torres, C.; Ben Hassen, A. First Description of KPC-2-Producing Escherichia coli and ST15 OXA-48-Positive Klebsiella pneumoniae in Tunisia. Microb. Drug Resist. 2017, 23, 365-375. [CrossRef]

35. Hassen, B.; Abbassi, M.S.; Ruiz-Ripa, L.; Mama, O.M.; Hassen, A.; Torres, C.; Hammami, S. High prevalence of mcr-1 encoding colistin resistance and first identification of bla ${ }_{C T X}-\mathrm{M}-55$ in ESBL/CMY-2-producing Escherichia coli isolated from chicken faeces and retail meat in Tunisia. Int. J. Food Microbiol. 2019, 318, 108478. [CrossRef] [PubMed]

36. Ruiz, E.; Saenz, Y.; Zarazaga, M.; Rocha-Gracia, R.; Martinez-Martinez, L.; Arlet, G.; Torres, C. Qnr, aac(6')-Ib-cr and qepA genes in Escherichia coli and Klebsiella spp.: Genetic environments and plasmid and chromosomal location. J. Antimicrob. Chemother. 2012, 67, 886-897. [CrossRef] [PubMed]

37. Clermont, O.; Bonacorsi, S.; Bingen, E. Rapid and Simple Determination of the Escherichia coli Phylogenetic Group. Appl. Environ. Microbiol. 2000, 66, 4555-4558. [CrossRef]

38. PubMLST. Escherichia Coli (Achtman) MLST Locus/Sequence Definitions Database. The Department of Zoology, University of Oxford, UK. Available online: https://pubmlst.org/bigsdb?db=pubmlst_ecoli_ achtman_seqdef (accessed on 20 May 2020).

39. Dutta, U.; Hossain, M.T.; Das, M.; Siddique, M.; Sarker, C.; Rana, M. Identification of microflora isolated from apparantly healthy camels in Bangladesh. Int. J. Biol. Res. 2010, 2, 1-6.

40. Al-Ruwaili, M.A.; Khalil, O.M.; Selim, S.A. Viral and bacterial infections associated with camel (Camelus dromedarius) calf diarrhea in North Province, Saudi Arabia. Saudi J. Biol. Sci. 2012, 19, 35-41. [CrossRef] [PubMed]

41. Fadlelmula, A.; Al-Hamam, N.A.; Al-Dughaym, A.M. A potential camel reservoir for extended-spectrum beta-lactamase-producing Escherichia coli causing human infection in Saudi Arabia. Trop. Anim. Health Prod. 2016, 48, 427-433. [CrossRef]

42. Ben Sallem, R.; Ben Slama, K.; Saenz, Y.; Rojo-Bezares, B.; Estepa, V.; Jouini, A.; Gharsa, H.; Klibi, N.; Boudabous, A.; Torres, C. Prevalence and characterization of extended-spectrum beta-lactamase (ESBL)and CMY-2-producing Escherichia coli isolates from healthy food-producing animals in Tunisia. Foodborne Pathog. Dis. 2012, 9, 1137-1142. [CrossRef]

43. Briñas, L.; Zarazaga, M.; Sáenz, Y.; Ruiz-Larrea, F.; Torres, C. Beta-lactamases in ampicillin-resistant Escherichia coli isolates from foods, humans, and healthy animals. Antimicrob. Agents Chemother. 2002, 46, 3156-3163. [CrossRef]

44. Baschera, M.; Cernela, N.; Stevens, M.J.A.; Liljander, A.; Jores, J.; Corman, V.M.; Nuesch-Inderbinen, M.; Stephan, R. Shiga toxin-producing Escherichia coli (STEC) isolated from fecal samples of African dromedary camels. One Health 2019, 7, 100087. [CrossRef]

45. Afema, J.A.; Ahmed, S.; Besser, T.E.; Jones, L.P.; Sischo, W.M.; Davis, M.A. Molecular epidemiology of dairy cattle-associated Escherichia coli carrying blaCTX-M genes in Washington State. Appl. Environ. Microbiol. 2018, 84, e02430-17. [CrossRef] 
46. Falgenhauer, L.; Imirzalioglu, C.; Oppong, K.; Akenten, C.W.; Hogan, B.; Krumkamp, R.; Poppert, S.; Levermann, V.; Schwengers, O.; Sarpong, N.; et al. Detection and Characterization of ESBL-Producing Escherichia coli From Humans and Poultry in Ghana. Front. Microbiol. 2019, 9, 3358. [CrossRef]

47. Ewers, C.; Bethe, A.; Semmler, T.; Guenther, S.; Wieler, L.H. Extended-spectrum $\beta$-lactamase-producing and AmpC-producing Escherichia coli from livestock and companion animals, and their putative impact on public health: A global perspective. Clin. Microbiol. Infect. 2012, 18, 646-655. [CrossRef] [PubMed]

48. Birgy, A.; Madhi, F.; Jung, C.; Levy, C.; Cointe, A.; Bidet, P.; Hobson, C.A.; Bechet, S.; Sobral, E.; Vuthien, H.; et al. Diversity and trends in population structure of ESBL-producing Enterobacteriaceae in febrile urinary tract infections in children in France from 2014 to 2017. J. Antimicrob. Chemother. 2020, 75, 96-105. [CrossRef] [PubMed]

49. Grönthal, T.; Österblad, M.; Eklund, M.; Jalava, J.; Nykäsenoja, S.; Pekkanen, K.; Rantala, M. Sharing more than friendship-transmission of NDM-5 ST167 and CTX-M-9 ST69 Escherichia coli between dogs and humans in a family, Finland, 2015. Eurosurveill. Eur. Commun. Dis. Bull. 2018, 23, 1700497. [CrossRef] [PubMed]

50. Hernandez, J.; Johansson, A.; Stedt, J.; Bengtsson, S.; Porczak, A.; Granholm, S.; González-Acuña, D.; Olsen, B.; Bonnedahl, J.; Drobni, M. Characterization and Comparison of Extended-Spectrum $\beta$-Lactamase (ESBL) Resistance Genotypes and Population Structure of Escherichia coli Isolated from Franklin's Gulls (Leucophaeus pipixcan) and Humans in Chile. PLoS ONE 2013, 8, e76150. [CrossRef]

51. Marques, C.; Belas, A.; Franco, A.; Aboim, C.; Gama, L.T.; Pomba, C. Increase in antimicrobial resistance and emergence of major international high-risk clonal lineages in dogs and cats with urinary tract infection: 16 year retrospective study. J. Antimicrob. Chemother. 2017, 73, 377-384. [CrossRef]

52. Ewers, C.; Bethe, A.; Stamm, I.; Grobbel, M.; Kopp, P.A.; Guerra, B.; Stubbe, M.; Doi, Y.; Zong, Z.; Kola, A.; et al. CTX-M-15-D-ST648 Escherichia coli from companion animals and horses: Another pandemic clone combining multiresistance and extraintestinal virulence? J. Antimicrob. Chemother. 2014, 69, 1224-1230. [CrossRef]

53. Pulss, S.; Stolle, I.; Stamm, I.; Leidner, U.; Heydel, C.; Semmler, T.; Prenger-Berninghoff, E.; Ewers, C. Multispecies and Clonal Dissemination of OXA-48 Carbapenemase in Enterobacteriaceae From Companion Animals in Germany, 2009-2016. Front. Microbiol. 2018, 9, 1265. [CrossRef]

(C) 2020 by the authors. Licensee MDPI, Basel, Switzerland. This article is an open access article distributed under the terms and conditions of the Creative Commons Attribution (CC BY) license (http://creativecommons.org/licenses/by/4.0/). 